\title{
It's not just about the destination, but also the journey: Reflections on research with Indigenous women food growers
}

\author{
Karyn Stein, ${ }^{a *}$ Miranda Mirosa, ${ }^{\mathrm{b}}$ and Lynette Carter $^{\mathrm{c}}$ \\ University of Otago
}

\begin{abstract}
Submitted September 30, 2016 / Revised February 16 and March 17, 2017 / Accepted April 5, 2017 /
Published online May 30, 2017

Citation: Stein, K., Mirosa, M., \& Carter, L. (2017). It's not just about the destination, but also the journey:

Reflections on research with Indigenous women food growers. Journal of Agriculture, Food Systems, and

Community Development, 7(3), 105-122. http://dx.doi.org/10.5304/jafscd.2017.073.003
\end{abstract}

Copyright (C) 2017 by New Leaf Associates, Inc.

\begin{abstract}
Research with Indigenous Peoples has a history associated with colonialism, oppression, and power and control dynamics. In order to work with Indigenous communities within a research context, unique methodologies encompassing Indigenous values, participatory approaches, and horizontal collaboration and/or knowledge exchange is required. The reflective essay explores how I (author Stein) utilized a blend of participatory and Indigenous research methodologies, including kaupapa Māori, which is unique to Māori of Aotearoa (New Zealand) and encompasses Māori

a * Corresponding author: Karyn Stein, $\mathrm{PhD}$ candidate, Te Whare Wānanga o Otāgo/University of Otago, Otepoti/ Dunedin, New Zealand; +64 7892 2963; karynstein@hotmail.com

b Dr. Miranda Mirosa, Senior Lecturer, Te Tari Pütaiao Kai/Department of Food Science, Te Whare Wānanga o Otāgo/University of Otago; P.O. Box 56; Otepoti/Dunedin 9054, Te Wai Pounamu/New Zealand; +64 3479 7953; miranda.mirosa@otago.ac.nz

c Lynette Carter, Senior Lecturer, Kai Tahu, Kati Mamoe, Waitaha, Te Tumu, School Māori, Pacific and Indigenous Studies, Te Whare Wānanga o Otāgo/University of Otago; P.O. Box 56; Otepoti/Dunedin 9054, Te Wai Pounamu/New Zealand; +64 3479 3049; lynette.carter@,otago.ac.nz
\end{abstract}

cultural values, aspirations, and tikanga (protocols). While the research explored how Māori women are reclaiming the food system and promoting agroecology, food self-reliance, and alternative visions based on Māori cultural values and traditions, this article is a reflective work based on my experiential learning through the process of utilizing a participatory methodology and kaupapa Māori. Nonetheless, I touch upon key research findings. The vastly opposing worldviews between Indigenous women promoting agroecological farming and the industrial model of food production are representative of the conflicting values of an Indigenous versus an academic worldview. In this paper, I set out a series of reflections on working with Indigenous Māori women within a research context; the challenges and tribulations that were overcome; as well as how kaupapa Māori, an Indigenous methodology, expands on participatory research.

\section{Keywords \\ Agroecology; Food Sovereignty; Indigenous Knowledge; Indigenous Methodologies; Indigenous Peoples; Kaupapa Māori; Knowledge Exchange; Participatory Approaches; Traditional Food Systems; Women; Gender}




\section{Introduction: Research, Colonization, and Indigenous Peoples}

This article is as much about the methodologies that I used along the way as it is about the research that I've been conducting over the last three years. As the old saying goes, it's not just about the destination, but also the journey. This encapsulates a perspective that is helpful for researchers to take when working with Indigenous Peoples (IP) and communities. My research focused on food selfreliance among Indigenous women and sought to understand how local gardening initiatives by and for Māori are reconnecting people with their food, culture, and the environment. In this article, I explore the obstacles, solutions, and lessons learned through a research process using a blend of participatory and Indigenous research methodologies.

Like other IP globally, Māori, the tangata whenua (people of the land) of Aotearoa (New Zealand) are overrepresented in statistics related to inequality, food poverty, and diet-related diseases such as diabetes and obesity. Māori have poverty rates double that of päkehà people (New Zealanders of European ancestry) (Perry, 2016). A higher rate of Māori youth (22.4\% compared with $9.1 \%$ of non-Māori youth) are not currently in the educational system or employed (Te Puni Kōkiri, 2012). Perry's (2016) report on household incomes in New Zealand from 1982 to 2015 defined poverty as living at less than $60 \%$ of the national median wage, which equates to about NZ\$28,000 per year, or approximately NZ $\$ 500$ per week. Māori are in the lowest group in terms of household income (Perry, 2016).

According to the New Zealand 2008/09 Adult Nutritional Survey, $59.1 \%$ of households were fully or almost fully food secure, $33.8 \%$ were moderately secure, and $7.1 \%$ had low food security status (University of Otago \& Ministry of Health, 2011). Pacific Islanders and Māori were the least food secure. Among Māori, only $34.8 \%$ were food secure, $48.7 \%$ were moderately secure, and $16.5 \%$ were food insecure (University of Otago \&, 2011). Overall, females were less food secure than males, with $56.5 \%$ of females being food secure as compared to $61.8 \%$ of males (University of Otago \& Ministry of Health, 2011).
Māori have difficulty accessing healthy food and are more likely to live in areas with limited access to quality supermarkets and an overabundance of fast food outlets (Te Hotu Manawa Māori, 2007). In addition, food insecurity is positively associated with obesity (Drewnowski \& Specter, 2004; Townsend, Peerson, Love, Achterberg, \& Murphy, 2001). Close to half (48\%) of Māori adults are considered obese, and 19\% of Māori children are obese (Ministry of Health, 2013). In a 2008 study by Lanumata, Heta, Signal, Haretuku, and Corrigan, Māori unanimously attested to the need for better access to nutritious foods, with most Māori, Pacific, and low-income research participants not always having access to the food they needed for a healthy life. The barriers they identified for living a healthy life included lack of money and the cost of healthy food (Lanumata et al., 2008). Similarly, research by MoekePickering, Heitia, Heitia, Karapu and Cote-Meek (2015) identifies barriers to healthy living that include access to healthy food and the depletion of food stocks due to pollution, resulting in a high dependence on purchasing food that is inexpensive, but not necessarily healthy. Participants in the study were concerned with how processed foods were affecting their health and "confidence in us to take back our land and to take back the sovereignty" (Moeke-Pickering et al., 2015, p. 37). Similarly, the women involved in my study identified the issues affecting Māori communities as having to do with environmental degradation, resource depletion, and economic inequalities, all of which are impacting access to healthy, sustainable, and culturally appropriate food.

My research began with a general interest in how food sovereignty is defined by Māori women and actualized on the ground in the form of community food initiatives led in particular by Māori women. This research was also inspired by the lack of Māori women's voices in scientific literature, underlying the need to highlight examples of Māori women taking the lead in devising innovative, empowering solutions to health, nutrition, food, and environmental issues impacting their whänau (families) and communities. Research on food security and community gardens within New Zealand is also limited, including a significant lack 
of Māori perspectives and the importance of Indigenous knowledge and values. Thus the aim of my research was to explore Māori women promoting food self-reliance, the meaning behind their actions, and the challenges they have faced along the way. As L. T. Smith (1999) states, our role as kaupapa Māori researchers is to listen and document Māori experiences and meanings.

A unique blend of kaupapa Māori and participatory research approaches informed this study. Kaupapa Māori is an Indigenous methodology that is context-specific and based on Māori cultural principles. It is specific to Māori, including Māori tikanga (protocol) and cultural values within the research process. Kaupapa Māori "speak[s] to pressing daily issues for [Māori]—food production, unemployment, access to resources and so on... Lately, a focus on food security, poverty, and health has come to surpass a focus on language and culture and even the environment" (G. H. Smith, Hoskins, \& Jones, 2012, p. 14).

The study took place over the course of three years and involved four Māori women as "case studies," who were leading local food initiatives. Three were located in the North Island of New Zealand and one in the South Island (Table 1). The four case studies were selected using purposeful sampling. All of the women were selected due to their knowledge of running a community initiative, growing food, and Māori culture. Because of the small sample size, the results of the study are not intended to be generalizable to the whole population, but rather offer insights into how a particular group of people perceive a problem, along with their opinions and ideas for solutions.

Research with IP has been criticized for being "disempowering" and "biased" (Davey \& Day, 2008; Kidman, 2007); however, the democratic, collaborative, and emancipatory nature of participatory research (Todhunter, 2001) is more historically and socially appropriate for IP. Its strong emphasis on social justice empowers those who have traditionally been the "objects" of research as "equal collaborators" instead (Brown \& Strega, 2005, p. 7). Relationships are based on mutual respect, equality, collaboration, and inclusivity (Reilly, 2010). This involves gaining an insider view of a particular issue, including personal perceptions and insights (Reilly, 2010). Most importantly, researchers need to be respectful and honor relationships (Kovach, 2005).

It is important to remember that just because research is focused on Māori, it does not mean it is within a kaupapa Māori framework (G. H. Smith, 2003). Within the scope of this project, Smith's kaupapa Māori principles underlay the development of the research and guided the study, including (1) the principle of ata, "spending quality time and effort to establish respectful and reciprocal relationships that include a transformative element"; (2) kia piki ake I nga raruraru o te kainga, "ensuring the research is of positive benefit to Māori communities and addresses socio-economic issues"; (3) tino rangatiratanga, "recognizing the principle of self-determination and the goal of control over one's own life and cultural well-being"; (4) taonga tuku iho, "assuring the centrality and legitimacy of te reo Māori (Māori language), tikanga (Māori protocol), and māturanga Māori (the Māori worldview), "that Māori ways of knowing, doing, and understanding are valid in their own right"; (5) kaupapa, "that the overall research topic contributes to a collective vision and purpose";

(6) whānau, "that the researcher recognizes their responsibility and obligation to the whanau (family) and respects the relationship between the researcher, researched, and research"; and (7) ako Māori, "ensuring the research methods, such as

Table 1. Participating Farm/Garden List

\begin{tabular}{lll}
\hline Case Study Participant & Farm/Garden & Location \\
\hline Charissa Waerea & Parihaka Community Garden & Parihaka, New Plymouth \\
\hline Lisa Isherwood & Awhi Farm & Turangi \\
\hline Ellen Baldwin & Motueka Community Garden & Motueka \\
\hline Hanui Lawrence & Aunty's Garden & Waipatu Marae, Hastings \\
\hline
\end{tabular}


oral traditions and storytelling, respect the culture and preferences of Māori”' (G. H. Smith, 2003, pp. 6-8).

Kaupapa Māori is change-oriented and focused on social action, where the knowledge bases of both researcher and participants are considered equal and roles are more egalitarian than traditional research relationships (Reilly, 2010). The goal of both participatory and kaupapa Māori research methodologies is to democratize knowledge making and to ground research in real community needs (Chevalier \& Buckles, 2013). With Māori communities overrepresented in poverty and food security statistics, this research is highly relevant to community needs. However, it goes beyond a focus on "food security," is a term that was formed in neoliberal discourse, does not take into account how or where food is produced, and lacks an understanding of the cultural, social, and historical significance of food. Research results have implications for policy development given the lack of adequate research on Māori women's perspectives on issues of hunger, malnutrition, and health impacts (obesity and/or diabetes) on their own communities.

\section{Indigenous and Participatory Research Methodologies: Community, Collaboration, and Learning}

Participatory research approaches are gaining traction in the social and environmental sciences (Brydon-Miller, Maguire, \& McIntyre, 2004; Jason, Keys, Suarez-Balcazar, Taylor, \& Davis, 2004; Kindon, Pain, \& Kesby, 2007a; Reason \& Bradbery, 2006). They are being used in community-based conservation and sustainable development to learn more about co-management practices, natural resource management, and enhance sustainable forestry, agriculture, ecological restoration, and wildlife management (Fortmann, 2008; Wilmsen, Elmendorf, Fisher, Ross, Sarathy, $\&$ Wells, 2008). They are also gaining prominence in the community development and health fields (Cornwall \& Jewkes, 1995), and are now widely promoted among international development agencies (Reilly, 2010). Participatory research is gaining in popularity among many Indigenous communities and projects, particularly in Canada, due to inherent critical, participatory, and collective principles (Kovach, 2005). Having worked in rural community development with Indigenous organizations in Guatemala and Belize for five years, I recognize that forming authentic relationships is the most important part of any collaborative process. Thus, throughout all stages of the research, the focus was on developing relationships with people involved in marae (a sacred Māori gathering place) or community gardens and farms, requiring substantial time and commitment. Data collection began in March 2015. As is typical with case studies, data collection occurred "over a sustained period of time" (Stake, 1995, quoted in Creswell, 2003, p. 15).

In Tobias, Richmond, and Luginaah's (2013) research with Indigenous communities, two researchers relocated and lived in close proximity to the communities during the data collection phase as a means to balance power. Similarly, I chose to relocate with my family to the North Island during the initial phases of the project in order to be in closer proximity to the women and initiatives, which allowed for more flexibility in arranging visits and more frequent interaction than otherwise would have been possible. This facilitated consistent contact and the building of trusting relationships. Participants were contacted and visited multiple times in order to establish trusting relationships before data collection began. Repeated contact with participants strengthens the rapport between the researcher and the participants, enhancing the richness of the data obtained (Tong, Sainsbury, \& Craig, 2007). In order to continue contact with the participants during the later stages of the research processes (data analysis and results dissemination), I decided to stay in the North Island through the end of the project. With participatory and Indigenous research approaches, the process is always dynamic and fluid.

Participatory research demands a significant investment in time and energy, as developing trustworthy relationships is particularly important (Davey \& Day, 2008; Reilly, 2010). Relationshipbuilding is the foundation of participatory research and, as mentioned above, began at the onset of the research project. My family and I met 
the women's families, visited marae, went to community bui (gatherings), shared meals, worked in the gardens and on the farm, and attended church with one of the women. I volunteered time through grant-writing for one of the projects, which secured NZ\$1,000 toward the costs of running the organization as a result. During the initial stages of development, the women contributed to the direction the research would take through a collaborative process. The women also voiced their interest in research addressing power and control dynamics in the food system, as well as examples of other initiatives that would take a holistic, integrated approach to food poverty. With an emphasis on whānau an integral part of kaupapa Māori, I met and formed connections with some of the women's families; the women also became close with my husband and daughter, who accompanied me on visits. The women also were vocal about being able to meet with one another when we discussed the other projects that were involved in the study. As a result, we made plans to obtain funding for exchanges among and between the women. Funding was difficult to obtain, but sufficient for one exchange. Face-toface visits were conducted after official data collection in order to get feedback on initial codes and the emergence of potential themes. During the exchange in Parihaka, participants had the chance to provide their feedback on the findings in a collective analysis of themes. Transcripts were returned to all participants to review and for comment. This added validity to the findings by ensuring the participants' perspectives were accurately represented (Popay, Rogers, \& Williams, 1998).

Realistically and in practice, participatory research is situation-specific, with collaboration and participation varying both among the research partners and throughout the stages of the research process (Israel, Schulz, Parker, Becker, Allen, \& Guzman, 2003). Kindon et al. (2007b) argue that choices about participation are made not just by the researcher, but "negotiated" between researcher and participants (p. 16). The researcher must be cognizant of not pressuring participants when or how much to participate, as participants should ultimately make the decision about how much participation they are comfortable with
(Kitchin, 2001). Within the context of this research, the total number of case studies was originally six, but cognizant of the apprehension of two case studies to participate, I did not pressure them, and they ended up not being involved with the study. Researchers must ensure that when they work with people, they understand that, depending on their circumstances and the situation, "various forms of participation may be valid at different times" (Kindon et al., 2007b, p. 16). Participation in this study fluctuated from initiative to initiative and throughout the research stages, a common issue when conducting participatory research. For example, the close proximity between my residence and Turangi, the location of Awhi Farm and within a 45-minute drive, facilitated continual collaboration with one participant, while the greater distance ( 4.5 hours) to Aunty's Garden meant fewer site visits. Ironically, the most site visits were made to Parihaka Community Garden, which was also 4.5 hours away, but Charissa Waerea was involved the longest, starting with the conceptual stages of the project. Hanui Lawrence, from Aunty's Garden in Hastings, began collaborating on the research during the later stages of data collection, and, coupled with greater distance to the project, her participation was more limited. However, I was able to connect with her at other times away from the garden. Regardless, attempts were made to balance the number of opportunities for in-depth discussion with each woman throughout the research process.

The project had three key areas of investigation: (1) How are Māori women promoting tino rangatiritanga of maara kai (self-determination with regard to food) within their whānau and community?; (2) What are some of the challenges and opportunities they face?; (3) How does community gardening fit within te ao Māori (worldview)? Within the sampling frame of the research, I strove to ensure that the initiatives included a diversity of forms (e.g., community gardens, marae gardens, and local farms) and that all included Māori women as coordinators playing a fundamental role in the establishment and ongoing running of the garden and/or farm. Additional criteria for selecting initiatives included being owned by and accessible to a variety of stakeholders. 
The study design was inherently flexible, which allowed for a degree of emergent sampling to take place with regard to Hanui Lawrence, Aunty's Garden, and Waipatu Marae, which came on board during the data collection phase of the research after one of the initial cases decided to no longer participate.

In addition, characteristics of community/ marae gardens and local farms in the study included:

- Locations on both the North Island (Awhi Farm, Parihaka Community Garden, and Aunty's Garden) and the South Island (Motueka Community);

- Vulnerable groups benefiting from the gardens, including elderly, people with low incomes, youth, etc.; and

- Diverse reasons for establishment (e.g., to promote sustainability, good health and/or nutrition, community food security and/or food self-reliance, for educational purposes, and to teach horticultural and/or permaculture skills).

It has been argued that "the key element of participatory research lies not in methods but in the attitudes of researchers, which in turn determine how, by and for whom research is conceptualized and conducted" (Cornwall \& Jewkes, 1995, p. 1667). Consulting participants may also want to know about the methods one is going to use, how long it is going to take, and who will be involved. I visited each of the women at least once before beginning the data collection stage of the research to explain more about the research, my intentions, and what was expected of them. I then conducted in-depth discussions. Two multiple-day visits to Parihaka Community Garden preceded in-depth discussions with Charissa Waerea, while four to five single-day visits to Awhi Farm preceded interviews/discussions with Lisa Isherwood. With Ellen Baldwin (Motueka Community Garden) and Hanui Lawrence (Aunty's Garden, Waipatu Marae), one initial introduction preceded in-depth interviews/ discussions. All of the women were also knowledgeable of my experience and background, which facilitated greater levels of comfort for when more in-depth discussions began.
A systematic approach to information gathering, analysis, and reflection was taken (Table 2). The research process was ongoing and cyclical, with steps continuously repeated (Hinchey, 2008). Data was collected through informal discussions and observation. Participant observation included working together with individual women/initiatives by assisting with grant-writing and helping in the gardens. Data was collected in an informal setting, typically at the gardens (Awhi Farm, Motueka Community Garden, and Aunty's Garden), with one (Parihaka Community Garden) at Charissa's office in Parihaka. Nobody else was present during the discussions, except for other gardeners who were out of earshot and involved in their own activities at the time. Questions were used to guide and prompt, but the interview/discussion structure remained very flexible and open. The interviews/ discussions were audio recorded, and field notes were also taken during visits and data collection. Interviews/discussions lasted from 2 to 3.5 hours. The study design was flexible enough to enable steady reflection and preliminary analysis. NVivo, qualitative data analysis software, was used to manage data, including the process of coding and identifying themes.

\section{Challenges Throughout the Research Process}

Four primary challenges arose: (1) bridging two worlds with differing worldviews; (2) understanding what was necessary in terms of commitment of time and energy, but not having the resources to do it (e.g., getting funding for multiple visits and exchanges); (3) explaining the project repeatedly to those in academia who were unfamiliar with what the project required (e.g., time and commitment) to be able to form trusting relationships with participants; and (4) using methodologies that are often questioned or disapproved of in an academic setting, but staying steadfast and believing in what I was doing. Common criticisms of participatory approaches include that researchers are not trained properly; they do not spend enough time in the field; they develop weak relationships; and their research entails inadequate participation (Ozanne $\&$ Sattcioglu, 2008). While participatory research and kaupapa Māori are distinct from each other, 
Table 2. Summary of Participatory/Kaupapa Research Process Specific to Project

\begin{tabular}{|c|c|c|c|}
\hline Research Step & Objectives & Methods & Outputs \\
\hline Initiating the project & $\begin{array}{l}\text { Identify potential Māori } \\
\text { focused and/or led mara kai } \\
\text { (food garden) projects }\end{array}$ & $\begin{array}{l}\text { Internet searches, outreach/estab- } \\
\text { lishing contact (emails/phone calls, } \\
\text { following leads) }\end{array}$ & $\begin{array}{l}\text { List of potential projects to } \\
\text { include in research }\end{array}$ \\
\hline Forming relationships & $\begin{array}{l}\text { Establish contact with women } \\
\text { leading mara kai projects }\end{array}$ & $\begin{array}{l}\text { Face-to-face visits to gauge interest } \\
\text { in the project. Initial site visits to } \\
\text { introduce myself, meet face to face, } \\
\text { and explain intentions and } \\
\text { proposed project and research } \\
\text { (Parihaka, Motueka, Awhi Farm, } \\
\text { with Tahuri Whenua AGM as } \\
\text { platform to meet with Hanui) }\end{array}$ & $\begin{array}{l}\text { Agreement to collaborate in } \\
\text { research project }\end{array}$ \\
\hline $\begin{array}{l}\text { Establishing } \\
\text { trustworthy } \\
\text { relationships }\end{array}$ & Strengthen relationships & $\begin{array}{l}\text { Second or more site visits to } \\
\text { discuss project and deepen } \\
\text { relationships (Parihaka, Awhi Farm) }\end{array}$ & $\begin{array}{l}\text { Research plan put in place; } \\
\text { participant research } \\
\text { interests defined }\end{array}$ \\
\hline $\begin{array}{l}\text { Documenting relevant } \\
\text { information }\end{array}$ & $\begin{array}{l}\text { Identify how Māori women } \\
\text { define food sovereignty and } \\
\text { associated cultural values }\end{array}$ & In-depth one-on-one interviews & $\begin{array}{l}\text { Transcripts and in-depth } \\
\text { data focused on research } \\
\text { questions }\end{array}$ \\
\hline Evaluating the data & $\begin{array}{l}\text { Review collected data } \\
\text { collected with the women and } \\
\text { analyze potential results }\end{array}$ & $\begin{array}{l}\text { One-on-one discussions to validate } \\
\text { transcripts and analyze emerging } \\
\text { themes }\end{array}$ & List of potential themes \\
\hline $\begin{array}{l}\text { Collaborate on } \\
\text { dissemination of } \\
\text { results }\end{array}$ & $\begin{array}{l}\text { Collectively review research } \\
\text { findings, identify missing } \\
\text { information }\end{array}$ & $\begin{array}{l}\text { Horizontal knowledge exchange for } \\
\text { women to share projects, informa- } \\
\text { tional workshops by and for women }\end{array}$ & $\begin{array}{l}\text { Summarizing research } \\
\text { results }\end{array}$ \\
\hline $\begin{array}{l}\text { Practical steps for- } \\
\text { ward: Informing policy, } \\
\text { future research, and } \\
\text { developing relevant } \\
\text { projects }\end{array}$ & $\begin{array}{l}\text { Identify potential areas for } \\
\text { future research and how } \\
\text { findings inform policy }\end{array}$ & $\begin{array}{l}\text { Community hui to share research } \\
\text { results and inform future actions }\end{array}$ & $\begin{array}{l}\text { Future action: Informal } \\
\text { exchanges to visit the other } \\
\text { initiatives }\end{array}$ \\
\hline
\end{tabular}

"they both share some common language" (Kovach, 2005, p. 23). Participatory research was initially developed in resistance to traditional research practices, which were often perceived as colonizing (Kemmis \& McTaggart, 2000). It represents a "counterhegemonic approach to knowledge production" (Kindon et al., 2007b, p. 9), and recognizes "the ongoing legacies of colonisation, modernistic development interventions, and positivistic research paradigms promoted by universitybased researchers" (Kindon et al., 2007b, p. 10). Both participatory and Indigenous methodologies focus on research participants having more control of the research process.

The time-intensive nature of participatory methodologies also involved financial obligations that were a major challenge that had to be overcome. Financial constraints necessitated the decision to move from the South to the North Island in order to be closer to participants to facilitate field visits, maintain consistent contact, and build trusting relationships. Financial constraints also made it difficult to visit the initiatives as much as I would have liked to. Many of my visits were self-funded, while exchanges among the women were limited to one gathering in Parihaka rather than all of the women visiting each of the projects, which would have been preferred. I applied for funding multiple times to facilitate such exchanges, and while a small amount was secured, Charissa (Parihaka) and I had to work together to figure out how we could make it happen on an extremely limited funding.

Relationships make the difference to the 
quality of data and transmission of information. When working with Indigenous organizations and communities, researchers may experience a general mistrust and apprehension to collaborate. Being non-Indigenous while working with Māori added another element of contention to the project. This was not a feeling I got from the participants, but rather from those in academia leery of work involving Indigenous communities given both a history of power differentials and a general lack of trust among IP toward research that may not serve their best interests. Though I see myself as an ally—working with, for, and among IP-I realize that others may not see me in that light and that my intentions were likely to be questioned, which underlies the importance of continually defining one's motivations and intentions both internally and externally.

Working with IP requires the researcher to reflect on power differences between him- or herself and the communities and/or people he or she is working with. Throughout the research, some of the women I was working with, as well as other researchers and academics, thought that I, being American, seemed to be more accepted among the women and communities than New Zealand päkeha (non-Indigenous people) might have been, as they are often seen as connected to colonization through their ancestry. There was some initial distrust given that the women and I were from different races and cultural backgrounds, but as women, we had some commonalities. However, I will never understand how it feels to be a minority and experience racism. It did seem that my experience working with Indigenous communities in Central America helped me to gain respect and earn the trust of some of the women, which contributed to my being viewed as an ally rather than a threat.

Being an ally to Indigenous communities entails working alongside IP to further their cause, protect their rights, and fight for environmental sustainability, Papatūannku (Mother Earth), and future generations. This was especially the case in Parihaka, where I spent the most time (even though it was a 4.5 hour drive away). This was attributable to the fact that I began visiting Parihaka during the initial stages of the project.
During these multiple day visits, I had the most community interaction, facilitated by monthly bui (gatherings) at which I was able to introduce myself and share some of my past experiences. The Parihaka $p \bar{a}$ (community) is highly organized and historically represents a seat of nonviolent resistance to colonization. From the first time I visited, I was welcomed with open arms and felt like whānau-an ally rather than an outsider through being genuine and honest.

The women I worked with directly perceived me as an ally in furthering their cause, focused on respect for Papatūānuku (Mother Earth), concern for future generations, and promoting sustainable food systems. Though there were imbalances between us related to my being in academia, these were overcome by relating to the women on their terms, person to person, and without talking down or in an overly academic and theoretical manner. Visiting the women with my husband and daughter -whom the women knew from infancy-also helped. With family highly valued and appreciated in Māori culture, this broke down many barriers that I may have otherwise experienced. Additionally, my husband and daughter are of Pacific Island descent; their also being a minority in New Zealand helped to strengthen relationships among the women and communities.

In addition, important ethical considerations and cultural concepts that guided the research process included seven Māori cultural values, as defined by Cram (2009) and L. T. Smith (1999):

(1) Aroha ki te tangata: Respect for those involved in the research process and allowing for the people involved to define where and when to meet;

(2) He kanohi kitea: Being a known and familiar face while facilitating trust and communication;

(3) Titiro, whakarongo...korero: Researchers should look, listen, and then speak, taking the time to establish relationships;

(4) Manaaki ki te tangata: Looking after people and ensuring genuine hospitality;

(5) Kia tupato: Researchers should be careful, cautious, culturally appropriate, and reflective; 
(6) Kaua e takahia te mana o te tangata: Collaborate with people and ensure their mana (dignity) is respected, recognizing that they are the experts over their own lives; and

(7) Kia mahaki: Be humble when sharing knowledge and understanding.

This research was approved by the Ngāi Tahu Research Consultation Committee as well as the University of Otago Human Ethics Committee. Participants agreed to participate and be identified in publications.

\section{Insights from Māori Women: Key Research Findings}

The results of the research generated a rich understanding of what food sovereignty means to Māori women, exemplifying ideas and practices that ensure cultural sustainability and continuance with regard to knowledge surrounding the importance of food production and mâra kai (food gardens). The seven themes that emerged are detailed in Table 3.

\section{Results for Social Change Through Exchange: The End is Just the Beginning}

Given the unequal power relations that have traditionally characterized research with IP, researchers should attempt to be as participatory and collaborative as possible. This is in direct contrast to the relative control that researchers normally have over the research process and places the researcher in a much more passive role. Sharing decision-making throughout the research process is key to undertaking participatory research with IP (Fröding, Elander, \& Eriksson, 2013; Israel et al., 2003). For me in this study, this included decisions on what areas the research would explore, with some women expressing interest in power and control dynamics in the food system as well as in learning more about other projects that are taking a holistic approach to food security issues. This more participatory approach also entailed continual contact with the women throughout all stages of the research process, rather than only during the data collection stage, as is usually the case with traditional research methods. Feedback was sought regarding the transcripts, during the initial formulation of the themes, and collectively agreeing on final themes. These methods "are seen less as means to an end than as offering ends in themselves: the emphasis is not on outcomes, but on processes" (Cornwall \& Jewkes, 1995, p. 1670).

While participatory research is useful for overcoming traditional power imbalances in research, incorporating culture-specific Indigenous research methodologies (in this case, kaupapa Māori) enhances the validity, reliability, and ethical soundness of the project. Indigenous methodologies integrate cultural values and protocols into the research process, and are "declared openly as part of the research design, to be discussed as part of the final results of the study, [and] to be disseminated back to the people in culturally appropriate ways and in a language that can be understood, as part of an ethical and respectful approach" (Smith, Hoskins, \& Jones, 2012, p. 16).

Kaupapa Māori provides the "lens through which the analysis was conducted, within a Māori worldview, and Māori women need to be involved, defining and telling their stories while analyzing situations pertinent to them" (Hutchings, 2004, p. 20). As the women illustrated when speaking about their reasons for doing what they are doing, diverse local food-based practices are about more than just growing food. They are about cultural values, such as history, traditions, sustainability, family, and children. These women are asserting their values through the food system, including the importance of community and tribe; traditions and ancestors; family and future generations; health and wellness; care for the Earth through agroecological farming; and self-determination and food selfreliance. For some, such as Charissa from Parihaka Community Garden and Lisa from Awhi Farm, it is also a way to challenge the corporate food system.

As the women express their love for the land and their duty to look after it, this reinforces claims that the land is a fundamental part of Māori existence, identity, and worldview (Durie, 2001). Papatuānuku, the Earth Mother, is where the people are from and where they will return, and thus Māori are tangata whenua, "not people in the land or over the land but people of it" (Jackson, 1993, p. 71). Papatūānuku is the "primal parent- 


\section{Table 3. Key Research Findings and Themes}

1. Community, Iwi (Tribe), and “It's all about people, community....It's open to anyone who wants to come. It's a community garden, It's Hapū (Subtribe) not a commercial garden. It's for families." - Hanui

"The most important resource we have is each other." -Charissa

"We have to be strong and work together." - Lisa

2. Traditions and Tipuna (Ancestors)

- Tikanga (Cultural protocol)

- Rongoā (Traditional Medicine)

"We grew up growing gardens...We grew crops for Watties canneries, Watties Heinz now. We grew peas and tomatoes, plus we grew all sorts of veggies for the gates sales. We had a little shop at the gate." -Hanui

"Part of my vision, living in Parihaka with successive children that are going to inherit what we leave them, is actually reliving or trying to reintroduce the old way of gardening that they [ancestors/previous inhabitants of Parihaka] had here that sustained big numbers." -Charissa

"Wild food and rongoā (traditional medicine) that we have-it's all interlinked, isn't it? Actually we just had a wild food harvest yesterday, going around, getting the plantain, the chickweed; there's actually plenty of food, people have just stepped away from it." - Lisa

"I was very little, but I can still remember how they [Ellen's parents] stored potatoes. They had to have a dark space for potatoes and stuff. They used to cover them with fern. I don't know much about the pits. I can't ever remember my parents using pits. They had a store room, an out place, an outhouse sort of thing. It would be all closed up. There would be no windows, just a door to go in, a sort of a bin type thing and all the crops used to go in there when storing them. Mom used to cut the fern, probably just for aeration, and the darkness, of course, to keep them stored." -Ellen

3. Whānau (Family) and Ngā Whakatūpuranga (Future Generations)

"The pathways are for children. I love to see them running around the place." -Hanui

"The children are the drive. We're supporting the drivers of change. It's all about the kids." -Lisa

"My mom and dad were keen gardeners." -Ellen

4. Gardens, Wellness, and Connecting to the Land

- Kaupapa Māori

"So for me, it's more about the total ecological system, not just gardening. But it's also, our connection to the earth by putting your hands in the soil you're reconnecting with our creators. Most activities we do these days there are often synthetic materials or business that prevents the contact we need to actually be having on a regular basis. So there's a lot of healing in that connection." -Charissa

"Oh, it's so good for you. It's the action, the fresh air, the layers of soil. It's all about the observation and the interaction between where you are-being present where you are, you know?" - Lisa

"If I didn't like gardening like I do, you wouldn't see me here for dust. It's because I like doing this. It's because I like doing what I do and I can see what comes out of what I do, and it makes me happy. It's good therapy for me to be down here working." -Ellen

5. Agroecological and Natural “It's all natural. I haven't given them [the plants] any [fertilizer] although we have a bit of a warm farm. And Farming Techniques

- Kakano (Seed) then some seaweed stuff that we put on occasionally, but this compost is very good." -Hanui

"So we're just looking at redeveloping a quarter acre [.1 hectare] for root crops. We're going to plow it, and we're going to put a winter crop in, a nitrogen fixing crop over this winter, and then we're planting corn and pumpkin, which are low maintenance crops for the first year, this coming summer." -Charissa

“There's a garden there [Ellen points to a plot near to where we're talking], and I'm seriously thinking about turning that into a seed garden and just put two plants from each thing that I think would be good to go to seed and have that as a garden just for seed." -Ellen

6. Ngā tā ke (Issues), Ngā piki “I'm afraid that when I stop running this, there will be no one else to do it, to carry on with it, at this me ngā heke (Ups and Downs/ Obstacles), Putanga mahi o te maara (Outcomes) moment in time. I mean, I'm 70." - Hanui

"There's a culture that still exists within us that we think its kind to feed the children sugar." -Charissa

"I do know that dependency on industrial food is the main problem. Every town has fast food dominance, and it feels like it's cheaper, but it's actually everything but healthy." - Lisa

"At the time when you're doing the garden they [community and family members] don't want to participate in growing the garden, but I just keep growing things, being a help, getting the guys to help me." -Ellen

7. Tino Rangatiratanga of Māra Kai (Food Sovereignty)

"I would define it as good food for the soul, that how I would say it, not like sovereignty." -Hanui

"My children have now learned, and to me, that's tino rangatiratanga [self-determination], it's providing the knowledge that they need to understand what is tika [right] and what isn't, so they can make informed decisions, whether they take those decisions is another things, but you've provided that information, and that to me, is what's most important, the provision of knowledge around what it is you put in your mouth." -Charissa

"Food sovereignty would be forest gardens, learning, and awareness of what's to come for generations ahead, which is climate change and a different way of sharing, of economics, because it's going to be more sacred than what it is now." - Lisa 
the first human was formed from the soil that cloaked Papatūānuku —all life depends on her for its well-being" (Harmsworth \& Roskruge, 2014, p. 123). As in research by Moeke-Pickering et al., participants thought it was important to protect knowledge for future generations, "grow their own kai [food] at their homes, on their Māori land trusts, at their marae, and to grow kai for their mokopuna [grandchildren] and kaumātua [elders]" (2015, p. 38; italic added). With regard to land tenure among these rural agricultural projects, three of the four are located on Māori tribal land (Auntie's Garden and Parihaka Community Garden are on or near to marae, and Awhi Farm is on Tuwharetoa tribal land). The other, Motueka Community Gardens, is located on town council land with a mutual agreement for a community garden. Three of the initiatives are considered semirural, located near or outside of small towns, and one, Parihaka, is rural.

It is important to note that while there are differences in circumstance regarding Indigenous Peoples throughout the world, there are also many similarities, including a common history of colonization resulting in loss of culture, land, and voice; health disparities, including socioeconomic positions and patterns of disease such as obesity, cancer, diabetes, and mental health issues; and, most importantly, worldviews, including a tradition of respect, identity, and connection with their environment (Durie, 2004). According to Rangitāne o Wairarapa Inc., people choose to "[care] for Papatūānuku to maintain their own health or [abandon] her to concentrate on their own shortterm personal needs; ultimately an unhealthy Papatūānuku will lead to unhealthy people" (2006, p. 6). For IP, their culture, food, and environment are intricately related (Panelli \& Tipa, 2009). Their traditional farming systems are not dependent on chemical inputs and not only yield more food energy per unit of energy used in production, but also rely on renewable energy sources (human labor, animals for hauling and plowing, and manure). This is in contrast to capital-intensive industrial agriculture, which depends heavily on climate-disrupting fossil fuels (Altieri, FunesMonzote, \& Petersen, 2012).

As food self-reliance or food sovereignty entails democratic control over food systems, participatory and Indigenous research methodologies entail active collaboration, which contributes to creating a "healthier and more sustainable environment" (Fröding et al., 2013, p. 32). Not only has there been a desire to improve practice through research, but also to "lead research through practice" (Haseman, 2006, p. 100), in this case by bringing into focus the incredible contributions that these women are making toward reforming our food system through the promotion of sustainable food production based on their personal and cultural values. Gardeners and farmers are more likely to listen and learn from their peers, especially if they are able to visit the farms and/or gardens and see them "with their own eyes," (Rosset, Sosa, Jaime, \& Lozano, 2011, p. 169). Kaupapa Māori is a participatory methodology based on a person's own culture, environment, and history; it "[takes] advantage of the rich pool of family and agricultural knowledge which is linked to their specific historical conditions and identities" (Rosset et al., 2011, p. 169). As demonstrated by the Māori women involved in the study, it fits well with the idea of exchanges. The Campesino-aCampesino (Farmer-to-Farmer) methodology of horizontal knowledge exchange and learning began in Central America (Rosset et al., 2011). The premise is that farmers and gardeners have solutions to problems they commonly face, often "rediscovered older traditional solutions" (Rosset et al., 2011, p. 169). The farmer-to-farmer method of exchange, while not as popular as in Central America, is also practiced in the Global North, including Europe (Schneider, Fry, Ledermann, \& Rist, 2009) and the U.S. (Hassanein \& Kloppenburg, 1995). We see a form of this exchange practiced in New Zealand with Tāhuri Whenua, a national Māori vegetable growers collective, representing Māori interests in the horticulture sector.

The Māori Women Food Growers Exchange occurred in Parihaka during a time the village usually gathers for their monthly hui (meeting) and was due all of the women's desire to connect with one another. Having traveled with my family to meet the women several times over the course of three years during this study, they all had heard of each other and wanted to connect in some way. 
While funding was originally sought for four exchanges so the women would be able to visit each initiative, ultimately we could only secure funding for one exchange. Given that I had the longest-standing relationship with Charissa in Parihaka and that the village gathers on a monthly basis, we decided to hold the exchange there (Figures 1-3). Hanui, who is also a member of Tāhuri Whenu, brought 200 tīpu (kumara seedlings) that the collective had donated to the exchange. Together, we prepared the land and planted the tipu, with the help of other members of the community, including the village leader. During our time in the māra kai, we were only allowed to

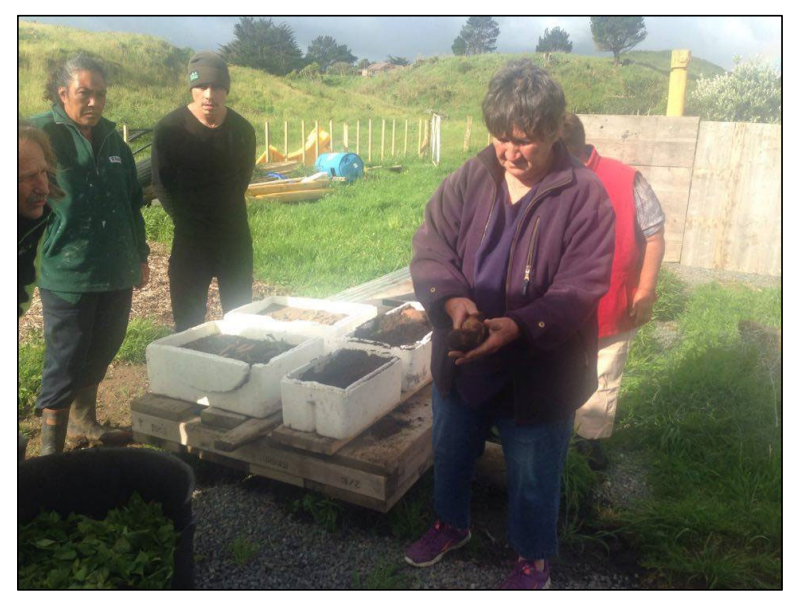

Figure 1. Hanui teaching about growing kumara tīpu (kumara seedlings) during the exchange in Parihaka.

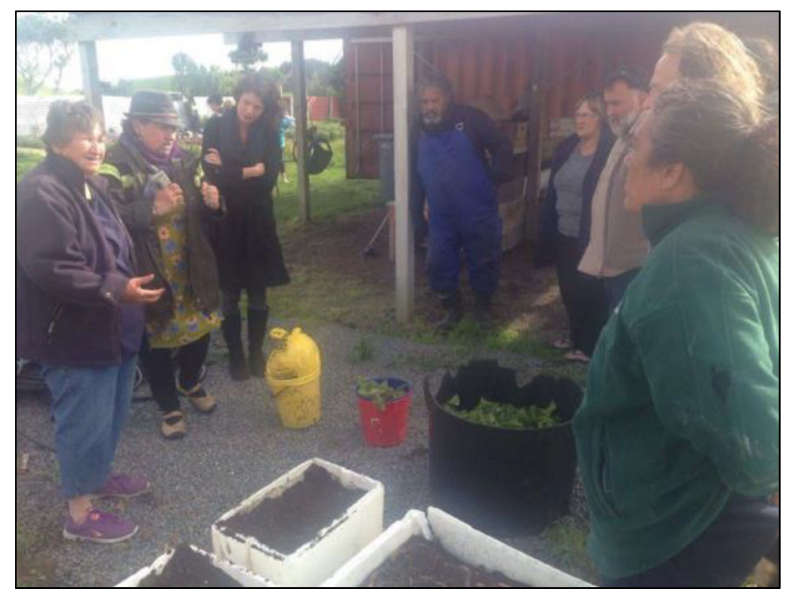

Figure 2. The garden as a classroom: Kumara workshop conducted as part of the Parihaka exchange. speak the Māori language in order to strengthen cultural awareness and identity, and again stay true to the tenants of kaupapa Māori, which emphasize the use of the Māori language and cultural revitalization. Given that the exchange was during a monthly hui usually held to commemorate Te Whiti and Tohu, Māori peace activists who practiced food cultivation as a way to claim land back from European settlers, this planting was especially significant. We also shared seed from each other's gardens, presentations, and photos from each of the women's projects, common problems and solutions encountered in the gardens, stories, and experiences. The village hui was for three days, during which we stayed collectively at the marae. Visitors from all over the country were there, including a school group with whom the women were also able to share their stories and experiences. The women also expressed the desire to continue the exchanges informally, without funding, by driving themselves to visit the other initiatives involved with the study.

\section{Policy Implications}

Actions to combat food poverty need to occur at the grassroots level and also entail a certain level of top-down policy change. A two-pronged approach, with both bottom-up and top-down change, is needed. According to De Schutter, the former United Nations Special Rapporteur, participation

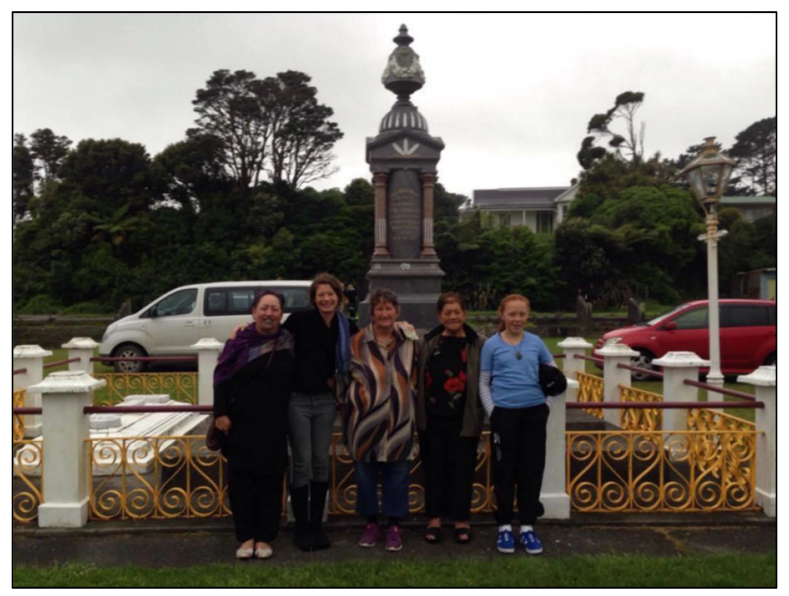

Figure 3. From left: Lisa Isherwood, Karyn Stein, Arohanui (Hanui) Lawrence, Ellen Baldwin, and Lisa's daughter Mary-Blossum in front of Te Whiti's statue in Parihaka. 
by the people affected by food poverty, including women, IP, and other vulnerable groups, is "key to the success of such a strategy... This ensur[es] that real needs are identified and effectively responded to. Participation further increases the awareness around the right to food and thus empowers people..." (2010, p. 7).

Policy changes are needed both at the top and to be integrated into community-level solutions (Bidwell, 2009). According to Pimbert, policies that allow for more democratic participation in the context of local food systems, agriculture, and the economy are essential (2009). Funding needs to be increased for agricultural research and food sciences that encompass participatory approaches, to "broaden citizen and non-specialist involvement in framing policies, setting research agendas and validating knowledge, as part of a process to democratize science, technology and policy making for food, farming, environment and development" (Pimbert, 2009, p. 11). In addition, what is needed is support for local food policy councils, rural/ urban linkages, local and/or regional procurement, and the elimination monopoly control of food and agricultural systems through anti-trust laws (International Assessment of Agricultural Knowledge, Science and Technology for Development [IAASTD], 2009).

Policies should support women in agriculture, particularly those practicing sustainable agroecological practices. Such agricultural policies should entail promoting access to productive resources, including land; support for exchanges and educational opportunities; infrastructure development for small farms and enterprises; and ensuring support for new farmers and those shifting to organic production. "Small-scale farmers - and women in particular-also need secure access to productive resources (e.g., land, water, and seeds), information, credit, and marketing infrastructure, as well as fair trade arrangements and supportive market conditions" (Ishii-Eiteman, 2009, p. 693). Public policies should facilitate farmer-to-consumer sales, for instance by providing infrastructure for farmers markets and also ensuring that third-party certification is affordable and more widely available (Ishii-Eiteman, 2009).

\section{Conclusion}

Cameron and Hicks emphasize the importance of researchers "being cognisant of the worlds that our research is helping to make more real" (2014, p. 68). Poverty and food insecurity are current issues being felt strongly in Māori communities, including malnutrition of essential nutrients due to the inadequate intake of fruits and vegetables, the increasing availability of cheap processed foods, and issues of obesity. Seyfang and Smith (2007) bring attention to grassroots projects, such as community gardening and farmers markets, that are often overlooked but offer "grassroots action for sustainability development" (p. 585). As academics, our roles are changing and being influenced by what is happening on the ground; as Gibson-Graham and Roelvink (2010) state, "we are being called to read the potentially positive futures barely visible in the present order of things, and to imagine how to strengthen and move them along" (p. 342).

The research results make the case for solutions to food poverty, especially when addressing food security in Indigenous communities, and take into account environmentally sustainable and socially just Māori cultural values. These solutions are also multifaceted, promoting agroecology and sustainable organic food production methods, especially in consideration of the environmental impacts of industrial agriculture. Given that conventional agriculture and the industrial food system are at the source of many problems Indigenous communities face, including obesity and readily available processed food, the women of this study all recognized the need for alternative solutions outside of the conventional food system and different from current top-down, compartmentalized approaches.

Within a context where Western values are embedded in and dictate the research process, traditional academic research methodologies remain rooted in power structures and colonialism $(\mathrm{L} . \mathrm{T}$. Smith, 1999). In line with participatory approaches, we need to "reinterpret what is meant by 'an original contribution to knowledge"" (Haseman, 2006, p. 100); in the context of this research, the focus was on improving practice through gaining an 'insider's understandings of action in context... 
rather than contribut[ing] to the intellectual or conceptual architecture of a discipline" (Haseman, 2006, p. 100). According to L. T. Smith, the process (consisting of both methodology and methods) is very important: it must be respectful, transformative, and contribute toward self-determination (1999). Climate change and resource depletion underpin the urgent need to question the dominant agri-industrial model and devise suitable alternatives to enhance resiliency and food security through crop diversification and local control of food systems. This study highlights the need to learn from the positive examples and experiences of Māori women leading local food initiatives. Research is about learning, reflecting, and challenging our worldviews. We need to make space for Indigenous values and world views in Western science, academic research, and society at large. As G. H. Smith, Hoskins, and Jones (2012) note, we need to "continue to make appropriate space for the validity of [Māori] ideas and ways of being" (p. 19).

In this case, the intention was to promote participation, critical thought, and creativity by utilizing a combination of methodologies to work with IP in a research context. Battiste, Bell, and Findlay's (2002) research with Aboriginal communities in Australia found that ownership over their own knowledge is essential and an important ethical principle. Bishop, Berryman, Powell, and Teddy (2005) also contend that Aboriginal communities have much concern over the control of research and who ultimately benefits. Kaupapa Māori reinforces the fact that the communities and people involved in the research should ultimately benefit from it. A key tenet of both participatory research and kaupapa Māori is that the research is useful and of positive benefit for communities (Israel et al., 2003). In both, researchers and participants collectively and critically examine an issue and build alliances throughout the research process, including the planning, implementation, and dissemination stages (McIntyre, 2008). In this study, this involved reclaiming, relearning, and revaluing the importance of traditional ways of growing "good" food, that is, growing in the natural way that the women's ancestors survived for thousands of years before the use of chemicals and pesticides.
The practical experience of working with the involved women and Indigenous communities has reinforced my theoretical knowledge surrounding participatory research, kaupapa Māori, and social learning exchanges. I can attest to the importance of integrating such methodologies into one's research through the deeply significant and trusting relationships I was able to form and the depth of knowledge and information the women were willing to share with both me and each other. There is no doubt that this was due to the time, energy, and commitment that participatory and kaupapa Māori theory and/or methodologies inherently entail. My deep level of trust of and commitment to such theories and methodologies have been repeatedly confirmed, previously while working with Indigenous communities in Central America and now in Aotearoa (New Zealand). Through the women's positive feedback regarding the Parihaka horizontal knowledge exchange, the importance of kaupapa Māori and participatory approaches was further solidified.

Finally, and most importantly, kaupapa Māori and participatory research methodologies share a common emphasis on transformation. According to G. H. Smith, Hoskins, and Jones (2012), this entails a certain level of action and personal transformative development. Transformation within a kaupapa Māori context is about making a difference in people's lives (G. H. Smith, Hoskins, \& Jones, 2012). Since research should be of benefit to those who contributed to it (Reilly, 2010), horizontal information exchanges among the women and initiatives during the research dissemination phase was beneficial in empowering women through meeting community leaders like themselves while also contributing to their ownership of the research and results. In this case, the exchange was the element of transformation in practice. As stated by Schneider et al., social learning approaches have become prominent in the field of sustainable agriculture; their study of "farmer-tofarmer" exchanges in Switzerland indicated "that processes of social learning led to fundamental transformations in patterns... of interactions" (2009, p. 487). Through the exchange, participants were able to enhance their knowledge, skills, leadership potential, and ability to affect change at 
an individual and collective level. Lisa expressed her deepfelt gratitude for the opportunity to be part of the exchange and to be inspired by likeminded individuals. Ellen went on to establish some plots in her community garden for her children and grandchildren, who are now taking a more active role in growing their own food. Hanui stated in a weekly newspaper editorial that the women spoke long into the night, relating ideas and experiences while invoking the true spirit of sharing through the kumara planting.

I presented the findings of the research in 2016 at the $11^{\text {th }}$ International Conference of Organic and Sustainable Agriculture in Cuba. As Charissa stated, the sharing of the research results and their voices in Cuba were exciting for all of us, as it represented an international platform for the women's knowledge and Māori cultural values to be shared. Farmers, gardeners, and academics in attendance greatly appreciated the cultural insights and environmental contribution of these women. Cuban food growers have been able to boost their organic food production through the Campesino-aCampesino (farmer-to-farmer) social process methodology, which they used to build a grassroots agroecology movement (Rosset et al., 2011).

The Māori women involved in this study attest to the positive benefits of community gardens for themselves, their families, and their local communities. By sharing experiences, the women were encouraged and motivated while their common struggles were recognized. The women were able to connect with like-minded individuals, consequently learning from each other, planting the seeds of future collaboration, and relieving felt isolation. The research attests to how Indigenous communities are going back to growing their own food, empowering themselves and others while also improving access to culturally appropriate, healthy food, as well as inspiring reconnection to the land and strengthening food sovereignty (Kamal, Linklater, Thompson, Dipple, \& Ithinto Mechisowin Committee, 2015).

\section{References}

Altieri, M. A., Funes-Monzote, F. R., \& Petersen, P. (2012). Agroecologically efficient agricultural systems for smallholder farmers: Contributions to food sovereignty. Agronomy for Sustainable Development, 32(1), 1-13. https://dx.doi.org/10.1007/s13593-011-0065-6

Battiste, M., Bell, L., \& Findlay, L. M. (2002). An interview with Linda Tuhiwai Te Rina Smith. Canadian Journal of Native Education, 26(2), 169-186.

Bidwell, S. (2009). Food security: A review and synthesis of themes from the literature. Christchurch: Canterbury District Health Board.

Bishop, R., Berryman, M., Powell, A., \& Teddy, L. (2005). Te Kotabitanga phase 2: Towards a whole school approach. Wellington: Ministry of Education.

Brown, L., \& Strega, S. (2005). Transgressive possibilities. In L. Brown \& S. Strega (Eds.), Research as resistance: Critical, Indigenous, and antioppressive approaches (pp. 1-17). Toronto: Canadian Scholars' Press/Women's Press.

Brydon-Miller, M., Maguire, P., \& McIntyre, A. (Eds.). (2004). Traveling companions: Feminism, teaching, and action research. Westport, Connecticut: Praeger.

Cameron, J., \& Hicks, J. (2014). Performative research for a climate politics of hope: Rethinking geographic scale, "impact" scale, and markets. Antipode, 46(1), 53-71. https://dx.doi.org/10.1111/anti.12035

Chevalier, J. M., \& Buckles, D. (2013). Participatory action research: Theory and methods for engaged inquiry. New York \& Abingdon: Routledge.

Cornwall, A., \& Jewkes, R. (1995). What is participatory research? Social Science \& Medicine, 41(12), 16671676. https://dx.doi.org/10.1016/02779536(95)00127-S

Cram, F. (2009). Maintaining Indigenous voices. In D.M. Mertens \& P.E. Ginsberg (Eds.), The Handbook of Social Research Ethics (pp. 308-322). Thousand Oaks, California: SAGE. https://dx.doi.org/10.4135/9781483348971.n20

Creswell, J. W. (2003). Research design: Qualitative, quantitative, and mixed methods approaches (2nd $\mathrm{Ed}$.). Thousand Oaks, California: SAGE.

Davey, L., \& Day, A. (2008). Reflections on methodology and process: A non-Indigenous perspective. In A. Day, M. Nakata, \& K. Howells (Eds.), Anger and Indigenous men: Understanding and responding to violent behaviour (pp. 151-157). Sydney: Federation Press. 
De Schutter, O. (2010). Countries tackling hunger with a right to food approach (Briefing Note 01). United Nations Special Rapporteur on the Right to Food. Retrieved from http://www2.ohchr.org/english/issues/ food/docs/Briefing Note 01 May 2010 EN.pdf

Drewnowski, A., \& Specter, S. E. (2004). Poverty and obesity: The role of energy density and energy costs. American Journal of Clinical Nutrition, 79(1), 6-16.

Durie, M. (2001). Mauri Ora: The Dynamics of Mãori Health. Oxford: Oxford University Press.

Durie, M. (2004). Understanding health and illness: Research at the interface between science and Indigenous knowledge. International Journal of Epidemiology, 33(5), 1138-1143. https://dx.doi.org/10.1093/ije/dyh250

Fortmann, L. (Ed.). (2008). Participatory research in conservation and rural livelihoods: Doing science together. Hoboken, New Jersey: Wiley-Blackwell.

Fröding, K., Elander, I., \& Eriksson, C. (2015). A community-based participatory research process in a poor Swedish neighbourhood. Systemic Practice and Action Research, 28(1), 19-36. https://dx.doi.org/10.1007/s11213-014-9319-y

Gibson-Graham, J. K., \& Roelvink, G. (2010). An economic ethics for the Anthropocene. Antipode, 41(Suppl. s1), 320-346. https://doi.org/10.1111/j.1467-8330.2009.00728.x

Harmsworth, G., \& Roskruge, N. (2014). Indigenous Māori values, perspectives and knowledge of soils in Aotearoa-New Zealand: Beliefs and concepts of soils, the environment, and land. In G. J. Churchman, E.R. Land (Eds.), The Soil underfoot: Infinite possibilities for a finite resource (pp. 111-126). Boca Raton, Florida: CRC Press. https://dx.doi.org/10.1201/b16856-12

Haseman, B. (2006). A manifesto for performative research. Media International Australia: Incorporating Culture and Policy, 118, 98-106.

Hassanein, N., \& Kloppenburg, J. R. (1995). Where the grass grows again: Knowledge exchange in the sustainable agriculture movement. Rural Sociology, 60(4), 721-740. http://dx.doi.org/10.1111/j.15490831.1995.tb00603.x

Hinchey, P. H. (2008). Action research. New York, New York: Peter Lang.

Hutchings, J. (2004). Claiming our ethical space: A mana wahine framework for discussing genetic modification. He Pukenga Korero, 8(1), 17-26.
International Assessment of Agricultural Knowledge, Science and Technology for Development [IAASTD]. (2009). Agriculture at a crossroads: International Assessment of Agricultural Knowledge, Science and Technology for Development (Synthesis Report). Washington, D.C.: Island Press.

Ishii-Eiteman, M. (2009). Food sovereignty and the International Assessment of Agricultural Knowledge, Science and Technology for Development 10. Journal of Peasant Studies, 36(3), 689-700. http://dx.doi.org/10.1080/03066150903143079

Israel, B. A., Schulz, A. J., Parker, E. A., Becker, A. B., Allen, A. J., \& Guzman, J. R. (2003). Critical issues in developing and following community based participatory research principles. In M. Minkler \& N. Wallerstein (Eds.), Community-based participatory research for health (pp. 53-76). San Francisco, California: Jossey-Bass.

Jackson, M. (1993). Land loss and the Treaty of Waitangi. In W. Ihimaera (Ed.), Te Ao Marama: Regaining Aotearoa: Māori Writers Speak Out, Vol 2: He Whakaatanga o te Ao: The reality (pp. 70-71). Auckland: Reed Books.

Jason, L. A., Keys, C. B., Suarez-Balcazar, Y., Taylor, R. R., \& Davis, M. I. (Eds.). (2004). Participatory community research: Theories and methods in action. Washington, DC: American Psychological Association.

Kamal, A. G., Linklater, R., Thompson, S., Dipple, J., \& Ithinto Mechisowin Committee. (2015). A recipe for change: Reclamation of Indigenous food sovereignty in O-Pipon-Na-Piwin Cree Nation for decolonization, resource sharing, and cultural restoration. Globalizations, 12(4), 559-575. https://dx.doi.org/10.1080/14747731.2015. 1039761

Kemmis, S., \& McTaggart, R. (2000). Participatory action research. In N. K. Denzin \& Y. S. Lincoln (Eds.), Handbook of qualitative research (pp. 567-607). Thousand Oaks, California: SAGE.

Kidman, J. (2007). Engaging with Māori communities: An exploration of some tensions in the mediation of social sciences research [Monograph]. Tihei Oreore Series. Auckland: Ngā Pae o te Māramatanga.

Kindon, S., Pain, R., \& Kesby, M. (Eds.). (2007a). Participatory Action Research approaches and methods: Connecting people, participation and place. New York: Routledge. 
Kindon, S., Pain, R., \& Kesby, M. (2007b). Participatory Action Research: Origins, approaches and methods. In S. Kindon, R. Pain, \& M. Kesby (Eds.), Participatory Action Research approaches and methods: Connecting people, participation and place (pp. 9-18). New York: Routledge.

Kitchin, R. (2001). Using participatory action research approaches in geographical studies of disabilities: Some reflections. Disability Studies Quarterly, 21(4), 61-69. https://dx.doi.org/10.18061/dsq.v21i4.318

Kovach, M. (2005). Emerging from the margins: Indigenous methodologies. In L. Brown \& S. Strega. (Eds.), Research as resistance: Critical, Indigenous and anti-oppressive approaches (pp. 19-36). Toronto: Canadian Scholars' Press/Women's Press.

Lanumata, T., Heta, C., Signal, L., Haretuku, R., \& Corrigan, C. (2008). Enhancing food security and physical activity: The views of Māori, Pacific and low-income peoples. Wellington: Health Promotion and Policy Research Unit, University of Otago. Retrieved from http://www.otago.ac.nz/ wellington/otago022604.doc

McIntyre, A. (2008). Participatory action research. Thousand Oaks, California: SAGE.

Ministry of Health (2013). New Zealand Health Survey: Annual update of key findings 2012/13. Wellington: Ministry of Health. Retrieved from http://www.health.govt.nz/publication/newzealand-health-survey-annual-update-key-findings$\underline{2012-13}$

Moeke-Pickering, T., Heitia, M., Heitia, S., Karapu, R., \& Cote-Meek, S. (2015). Understanding Māori food security and food sovereignty issues in Whakatāne. MAI Journal, 4(1), 29-42.

Ozanne, J. L., \& Sattcioglu, B. (2008). Participatory action research. Journal of Consumer Research, 35(3), 423-439. https://dx.doi.org/10.1086/586911

Panelli, P., \& Tipa G. (2009). Beyond foodscapes: Considering geographies of Indigenous Well-being. Health \& Place, 15(2), 455-65. https://dx.doi.org/ 10.1016/j.healthplace.2008.08.005

Perry, B. (2016). Household Incomes in New Zealand: Trends in indicators of inequality and hardship 1982 to 2015. Wellington: Ministry of Social Development.

Pimbert, M. (2009). Towards food sovereignty (Gatekeeper Series No. 141). London: International Institute for Environment and Development (IIED). Retrieved from https://www.iied.org/towards-foodsovereignty-reclaiming-autonomous-food-systems

Popay, J., Rogers, A., \& Williams, G. (1998). Rationale and standards for the systematic review of qualitative literature in health services research. Qualitative Health Research, 8(3), 341-351. https://dx.doi.org/10.1177/104973239800800305

Rangitāne o Wairarapa Inc. (2006). Ngāti Hāmua environmental education sheets. Greater Wellington Regional Council. Masterton: Lamb-Peters Print.

Reason, P., \& Bradbury, H. (Eds.). (2006). Handbook of action research. Thousand Oaks, California: SAGE.

Reilly, R. C. (2010). Participatory case study. In Encyclopedia of case study research (Vol. 2, pp. 658-660). Thousand Oaks, California: SAGE.

Rosset, P. M., Sosa, B. M., Jaime, A. M. R., \& Lozano, D. R. A. (2011). The Campesino-to-Campesino agroecology movement of ANAP in Cuba: Social process methodology in the construction of sustainable peasant agriculture and food sovereignty. The Journal of Peasant Studies, 38(1), 161-191. https://dx.doi.org/10.1080/03066150.2010.538584

Schneider, F., Fry, P., Ledermann, T., \& Rist, S. (2009). Social learning processes in Swiss soil protectionThe 'From farmer-to-farmer' project. Human Ecology, 37(4), 475-489. https://dx.doi.org/10.1007/s10745-009-9262-1

Seyfang, G., \& Smith, A. (2007). Grassroots innovations for sustainable development: Towards a new research and policy agenda. Environmental Politics, 16(4), 584-603. http://dx.doi.org/10.1080/09644010701419121

Smith, G. H. (2003, October). Indigenous struggle for the transformation of education and schooling. Retrieved from https:// faculty.washington.edu/ pembina/all_articles/Smith_G2003.pdf

Smith, G. H., Hoskins, T. K., \& Jones, A. (2012). Interview: Kaupapa Māori: The dangers of domestication. New Zealand Journal of Educational Studies, 47(2), 10-20.

Smith, L. T. (1999). Decolonizing methodologies: Research and Indigenous Peoples. London: Zed Books.

Te Hotu Manawa Māori. (2007). Food security among Māori in Aotearoa. Auckland: Author.

Te Puni Kōkiri. (2012). Māori youth in education and employment (Fact sheet 022-2012). Retrieved from https://www.tpk.govt.nz/documents/download/2 10/TPK $\% 20$ Maori $\% 20$ Youth $\% 20$ in $\% 20$ Education \%20WEB.pdf 
Tobias, J. K., Richmond, C. A. M., \& Luginaah, I. (2013). Community-based participatory research (CBPR) with Indigenous communities: Producing respectful and reciprocal research. Journal of Empirical Research on Human Research Ethics, 8(2), 129-140.

https://dx.doi.org/10.1525/jer.2013.8.2.129

Todhunter, C. (2001). Undertaking action research: Negotiating the road ahead. University of Surrey Social Research Update, 34. Retrieved May 4, 2016, from http://www.soc.surrey.ac.uk/sru/SRU34.html

Tong, A., Sainsbury, P., \& Craig, J. (2007). Consolidated criteria for reporting qualitative research (COREQ): A 32-item checklist for interviews and focus groups. International Journal for Quality in Health Care,
19(6), 349-357.

https://dx.doi.org/10.1093/intqhc/mzm042

Townsend, M. S., Peerson, J., Love, B., Achterberg, C., \& Murphy, S.P. (2001). Food insecurity is positively related to overweight in women. Journal of Nutrition, 131(6), 1738-1745.

University of Otago \& Ministry of Health. (2011). A Focus on Nutrition: Key findings of the 2008/09 New Zealand Adult Nutrition Survey. Wellington: Ministry of Health.

Wilmsen, C., Elmendorf, W., Fisher, L., Ross, J., Sarathy, B., \& Wells, G. (Eds.). (2008). Partnerships for empowerment: Participatory research for community-based natural resource management. New York: Routledge. 